\title{
DESIGN, MOLECULAR MODELING AND SYNTHESIS OF NEW IMMUNOMODULATORY AGENTS FOR BIOLOGICAL STUDIES
}

\author{
Maged Mohammed Saleh Al Ward ${ }^{1}$, Rezk Ayyad ${ }^{1}$, Mohamed F. Zayed ${ }^{1}$, Abdallah E. \\ Abdallah $^{1}$, Mohamed Ayman Aly El-Zahabi ${ }^{1 *}$ \\ ${ }^{1}$ Pharmaceutical Medicinal Chemistry \& Drug Design Department, Faculty of \\ Pharmacy (Boys), Al-Azhar University, Cairo, Egypt \\ corresponding author Email: malzahaby@azhar.edu.eg
}

\begin{abstract}
Cancer is the second leading cause of death worldwide. This work is an effort to find new effective and safe anticancer agents. In accordance with thalidomide features as immunomodulator anticancer drug, we designed and synthesized ten new thalidomide analogs. The synthesized compounds were biologically evaluated for their anti-tumor activity against three human cancer cell lines namely; hepatocellular carcinoma (HepG2), prostate cancer (PC3) and breast cancer (MCF-7). Thalidomide was used as a reference drug. The obtained data showed that compound 10a is far better than thalidomide against the three cancer cell lines. It exhibited $\mathrm{IC}_{50}=3.89,4.01$ and $2.91 \mu \mathrm{g} / \mathrm{mL}$ against the cell lines, respectively. While thalidomide exhibited $\mathrm{IC}_{50}$ values of $11.26,14.58$, and $16.87 \mu \mathrm{g} / \mathrm{mL}$ against the three cell lines, respectively. Moreover, compounds 7a, $6 \mathbf{a}$ and $\mathbf{8}$ were found to be better than thalidomide against MCF-7 cell line. As they showed $\mathrm{IC}_{50}$ values of $10.32,12.15$ and $15.32 \mu \mathrm{g} / \mathrm{mL}$, respectively. Furthermore, compounds $\mathbf{6 a}, \mathbf{7 a}$, and $\mathbf{8}$ showed strong activity against the three cell lines. Results of docking studies showed that our compounds can accommodate the pocket of CRBN with binding energies too close to that of thalidomide.
\end{abstract}

Key words: Anticancer, immunomodulator, thalidomide 


\section{1- Introduction}

Cancer is a life threatening disease and is reported as the second leading cause of death worldwide(Siegel, Miller, and Jemal 2020)(Jemal et al. 2008). At the same time nonselective chemotherapeutic agents are known to cause severe side effects (Mac Donald 2012). These two points strongly encourage us to develop new effective and safe anticancer agents. One of the promising safe and effective approach to cancer treatment is the development of immunomodulatory agents (Fernández-Lázaro et al. 2018).

Thalidomide (I) (Fig. 1) is an immunomodulator anticancer drug of a particular significance (Jin et al. 2013). It is a synthetic glutamic acid derivative originally marketed as a sedative and antiemetic in 1954. However, in 1961 it was quickly withdrawn from distribution when its teratogenic properties were discovered (Ito et al. 2010). Several years later the serendipitous finding that thalidomide could allay the symptoms of erythema nodosum leprosum (ENL) led to its re-emergence as a treatment for various pro-inflammatory and autoimmune conditions (Okafor 2003). In 1994, speculation that thalidomide teratogenicity is linked to the repression of angiogenesis (Ito, Ando, and Handa 2011) resulted in a new wave of clinical investigations that expanded the use of thalidomide for the treatment of various malignancies, including multiple myeloma (MM) (Singhal et al. 1999), melanoma, renal-cell carcinoma and prostate cancer (Eleutherakis-Papaiakovou, Bamias, and Dimopoulos 2004). Thalidomide was given FDA approval for the treatment of acute ENL in 1998, after further investigations found an immunological basis for this effect. It also received FDA approval in 2006 for the treatment of newly diagnosed MM (Diggle 2001).

Modification of thalidomide afforded anticancer drugs of significant activity e.g. lenalidomide (II) (Lopez-Girona et al. 2012), pomalidomide (III) (Lopez-Girona et al. 2012) and CC-122 (IV) (Fig.1) (Hagner et al. 2015).

lenalidomide (II) was found to be more potent than thalidomide as an inhibitor of TNF- $\alpha$ (Akobeng and Stokkers 2009). In 2006, it was approved by FDA for treatment of MM (Attal et al. 2012).

pomalidomide (III) was 10 -fold more potent than lenalidomide (2) as a TNF- $\alpha$ inhibitor and interleukin-2 (IL-2) stimulator (Galustian and Dalgleish 2011). It also showed better anti-angiogenic results than thalidomide (1) and lenalidomide (2). In 2013, FDA approved pomalidomide for the treatment of MM (Offidani et al. 2014). 
<smiles>O=C1CCC(N2C(=O)c3ccccc3C2=O)C(=O)N1</smiles>

Thalidomide (I)<smiles>Nc1cccc2c1CN(C1CCC(=O)NC1=O)C2=O</smiles>

Lenalidomide (II)<smiles>Nc1cccc2c1C(=O)N(C1CCC(=O)NC1=O)C2=O</smiles><smiles>Cc1nc2cccc(N)c2c(=O)n1C1CCC(=O)NC1=O</smiles>

Pomalidomide (III)

Figure 1: Structure of thalidomide and some of its analogs

CC-122 draw attention as one of thalidomide analogs. It showed potent antiproliferative, immunomodulatory and anti-angiogenic activities with a potentially broader range of activity than lenalidomide (P. et al. 2014). It was found to be effective against diffuse large B-cell lymphoma (DLBCL), multiple myeloma (MM) and solid tumors (Hagner et al. 2015), (T. et al. 2010). In line with the approach of thalidomide modification, we designed new analogs for anticancer testing.

\section{2- Rationale and design}

Modification of thalidomide was carried out at three positions as illustrated in Fig. 2. The first position is phthalimido moiety which was replaced by benzodiazine (quinoxaline) which is a bioisostere to quinazoline of CC-122. This is because thalidomide is not a flexible compound. As glutarimido moiety is almost perpendicular to phthalimido moiety and the rotation around the sigma bond between them is highly restricted due to steric effect. To increase the rotation and flexibility of our compounds the five membered heteroaromatic ring was replaced with six membered ring. The second site of modification was the glutarimido moiety. It was replaced with sulfonylpiperazine, piperazinocarboxamide and piperazinocarboxylate. These moieties are able to form Hydrogen. bonds as glutarimide moiety with better flexibility. The third modification was the addition of a terminal hydrophobic group to study the effect of this extension on activity. Several compounds with similar extensions were reported to have promising activities (see Fig.3). 


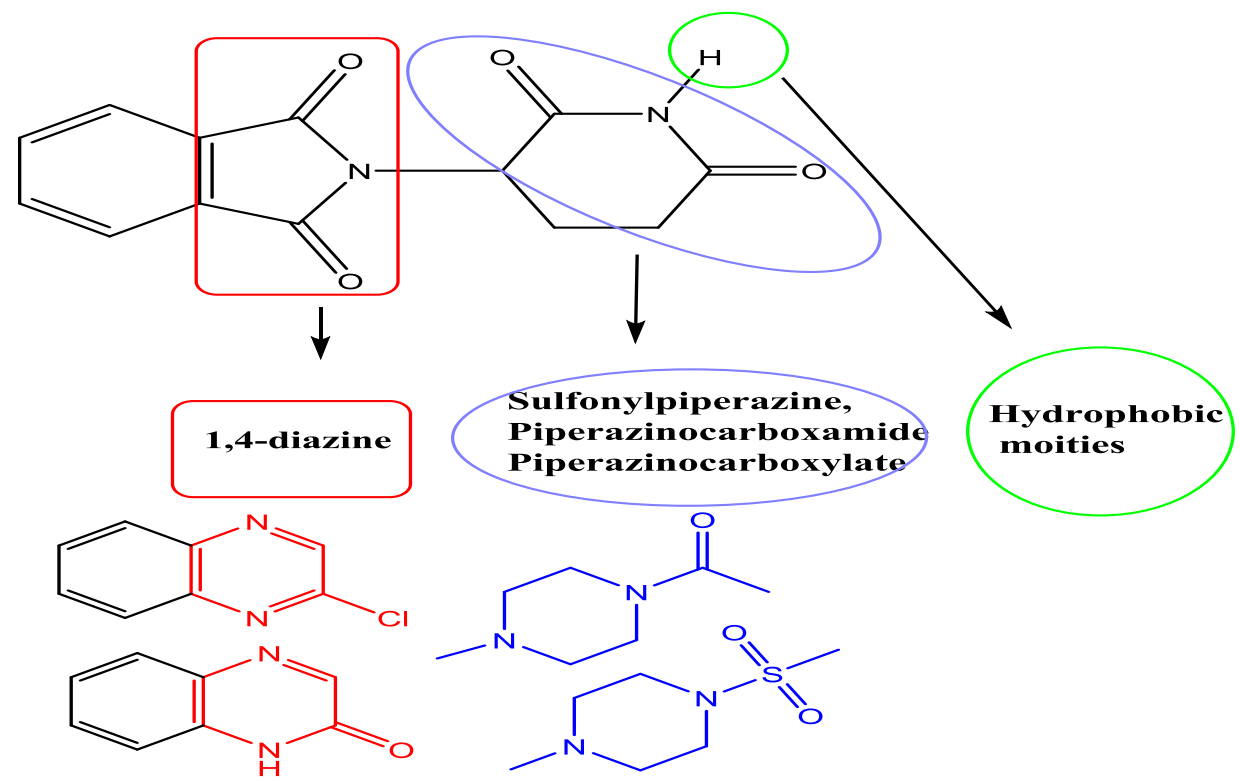

Figure 2: The proposed modification of thalidomide as a lead compound in our molecules design. 

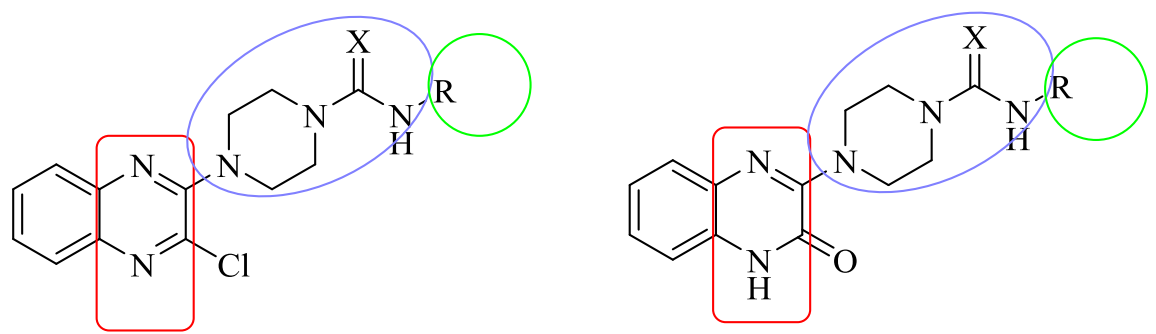

$\mathrm{X}=\mathrm{S}, \mathrm{O}$

$\mathrm{R}=\mathrm{C}_{6} \mathrm{H}_{5}, \mathrm{C}_{6} \mathrm{H}_{11}$

$\mathrm{X}=\mathrm{S}, \mathrm{O}$

$\mathrm{R}=\mathrm{C}_{6} \mathrm{H}_{5}, \mathrm{C}_{6} \mathrm{H}_{11}$
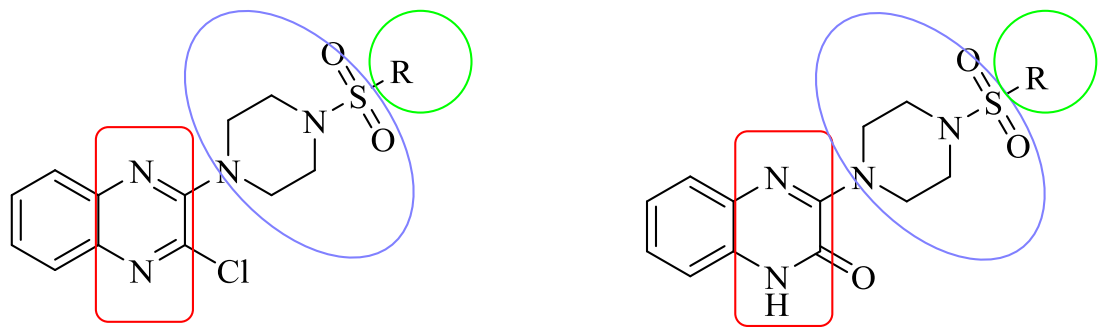

$\mathrm{R}=$ phenyl,p-tolyl

$\mathrm{R}=$ phenyl,p-tolyl
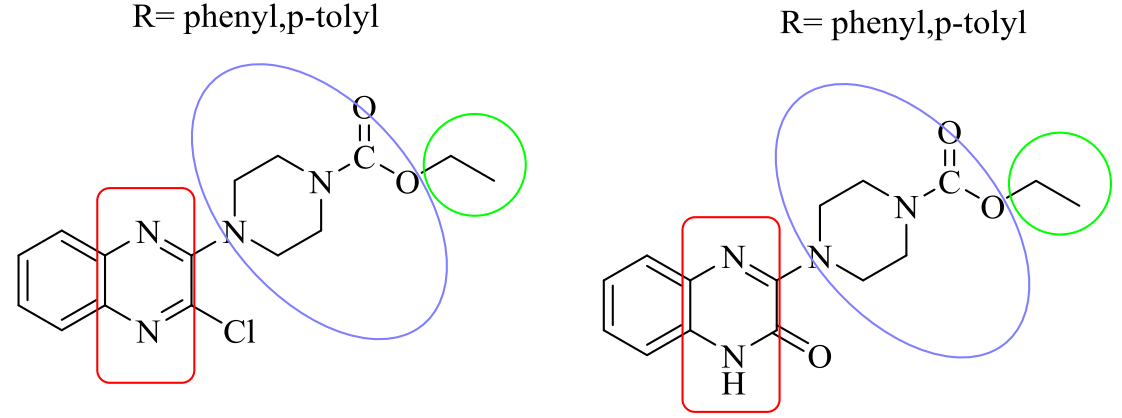

1,4-Diazine

Sulfonylpiperazine,

Piperazinocarboxamide

Piperazinocarboxylate

Hydrophobic moities

Figure 3: The synthesized compounds showed different structure modification

\section{3- Results and discussion}

\subsection{Chemistry}

Quinoxaline-2,3-dione 3 was obtained by refluxing of $o$-phenylenediamine and oxalic acid in $4 \mathrm{~N} \mathrm{HCl}$. Quinoxaline-2,3-dione was then heated in $\mathrm{POCl}_{3}$ to afford 2,3dichloroquinoxaline (4). Reaction of compound $\mathbf{4}$ with piperazine was carried out in ethanol under reflux temperature as illustrated in Scheme 1. 
<smiles>Nc1ccccc1N</smiles>

1<smiles>O=C(O)C(=O)O</smiles>

2<smiles>Clc1nc2ccccc2nc1N1CCNCC1</smiles>

5

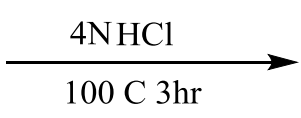<smiles>C1CNCCN1</smiles>

refluxing/ ethanol<smiles>O=c1[nH]c2ccccc2[nH]c1=O</smiles>

3

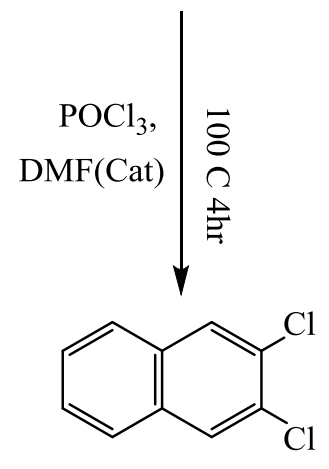

4

Scheme 1: Chemical synthesis of the target compound 5

2-Chloro-3-piperazinoquinoxaline (5) was used as starting material for the preparation of final compounds $\mathbf{6}_{\mathrm{a} \& \mathrm{~b}}, \mathbf{7}_{\mathrm{a} \& \mathrm{~b}}$, and 8 as shown in scheme2. Refluxing of compound 5 with phenyl or cyclohexyl isocynate afforded the final compounds $\mathbf{6}_{\mathbf{a} \& \mathbf{b}}$, respectively. While addition of benzenesulfonyl chloride or 4-methylbenzenesulfonyl chloride dropwise to compound $\mathbf{5}$ in DMF gave the final compounds $\mathbf{7}_{\mathrm{a} \& b}$. At the same manner addition of ethyl chloroformate dropwise to compound $\mathbf{5}$ in DCM gave compound $\mathbf{8}$. 

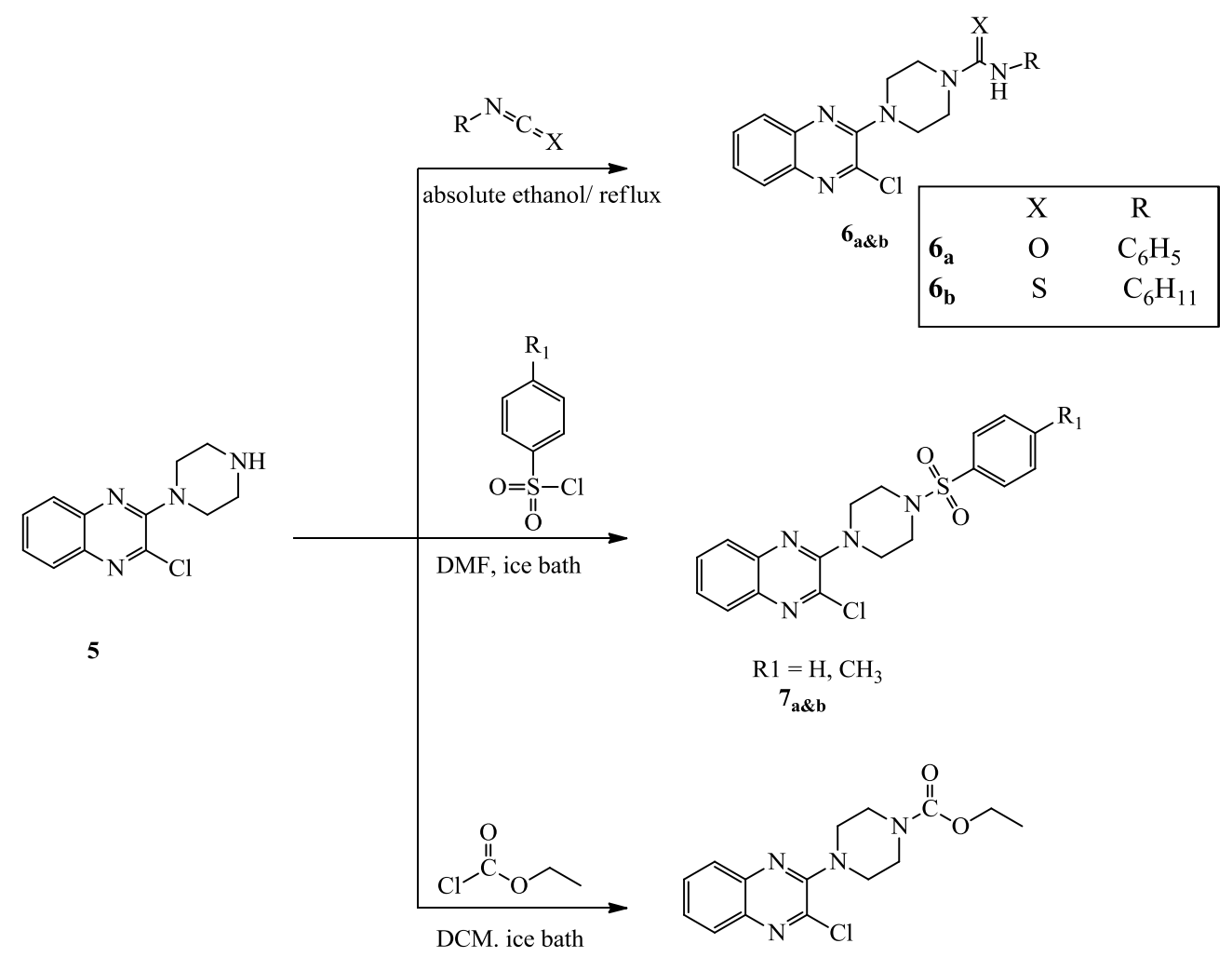<smiles>CCOC(=O)N1CCN(c2nc3ccccc3nc2Cl)CC1</smiles>

Scheme 2: Chemical synthesis of the target compounds $6 a \& b, 7 a \& b$ and 8

Scheme 3 shows that stirring of compound 5 in aqueous $\mathrm{NaOH}$ solution afforded 3piperazinoquinoxaline-2-one (9). Refluxing of compound 9 with phenyl isocyanate and cyclohexyl isothiocynate afforded the final compounds $\mathbf{1 0}_{\mathbf{a} \& \mathbf{b}}$ respectively. At the same time the final compounds $\mathbf{1 1}_{\mathbf{a} \& \mathbf{b}}$ were obtained by addition of benzenesulfonyl chloride or 4-methylbenzenesulfonyl chloride to compound 9. While addition of ethyl chloroformate dropwise to compound 9 in DCM gave compound 12. 
<smiles>Clc1nc2ccccc2nc1N1CCNCC1</smiles>

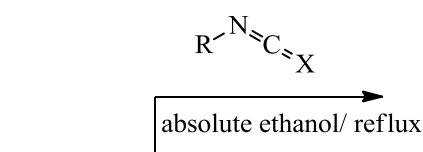<smiles>CC(C)CNON</smiles>

9<smiles>[R]NC([X])N1CCN(c2nc3ccccc3[nH]c2=O)CC1</smiles><smiles>[R1][Y11]([H])=C1Nc2ccccc2N=C1N1CCN(S(=O)(=O)c2ccc([R7])cc2)CC1</smiles><smiles>CCOC(=O)N1CCN(c2nc3ccccc3[nH]c2=O)CC1</smiles>

Scheme 3: Chemical synthesis of the target compounds $10 \mathbf{a} \& \mathbf{b}, \mathbf{1 1 a} \& \mathbf{b}$ and 12

\subsection{Biology}

\section{In vitro Antiproliferative assay}

All the final compounds were tested for their antitumor activity against three human cancer cell lines namely; hepatocellular carcinoma (HepG2), prostate cancer (PC3) and breast cancer (MCF-7). Thalidomide was tested as a reference drug. The data presented in Table 1 show that compound $\mathbf{1 0}_{\mathbf{b}}$ is the most active candidate with very potent antitumor activity against the three cell lines. We can see that it is far better than thalidomide in this test. As it showed $\mathrm{IC}_{50}=3.89,4.01$ and $2.91 \mu \mathrm{g} / \mathrm{mL}$ against the cell lines, respectively. While thalidomide exhibited $\mathrm{IC}_{50}$ values of $11.26,14.58$, and 16.87 $\mu \mathrm{g} / \mathrm{mL}$ against the three cell lines, respectively. It was found that compounds $7 \mathbf{a}, \mathbf{6 a}$, and $\mathbf{8}$ were better than thalidomide against MCF-7 cell line, as they showed $\mathrm{IC}_{50}$ values of $10.32,12.15$ and $15.32 \mu \mathrm{g} / \mathrm{mL}$, respectively. Also it can be seen that compound $7 \mathbf{a}$ demonstrated nearly the same activity of thalidomide against HepG-2. Moreover, compounds 6a, 7a, 8 showed strong activity against the three cell lines. While the other compounds showed moderate activities. No compound was found to be weak or 
inactive. Furthermore, the breast cancer cell line was found to be the most sensitive to the effect of our compounds.

Table 1: $\mathrm{IC}_{50}$ of the final compounds and thalidomide against ; HepG2, PC3 and MCF7 cell lines.

\begin{tabular}{|l|l|l|l|l|}
\hline \multirow{2}{*}{ Serial } & \multirow{2}{*}{ Comp. no. } & \multicolumn{3}{|c|}{$\mathrm{IC}_{50}(\mu \mathrm{g} / \mathrm{mL})$} \\
\cline { 3 - 5 } & & HePG2 & PC3 & MCF-7 \\
\hline 1 & $\mathbf{6 a}$ & $17.01 \pm 1.3$ & $19.51 \pm 1.4$ & $12.15 \pm 1.2$ \\
\hline 2 & $\mathbf{6 b}$ & $22.72 \pm 1.7$ & $31.07 \pm 1.23$ & $25.07 \pm 1.53$ \\
\hline 3 & $\mathbf{7 a}$ & $11.81 \pm 0.82$ & $19.28 \pm 1.3$ & $10.32 \pm 0.93$ \\
\hline 4 & $\mathbf{7 b}$ & $35.07 \pm 1.63$ & $41.07 \pm 1.73$ & $30.07 \pm 1.33$ \\
\hline 5 & $\mathbf{8}$ & $16.37 \pm 1.7$ & $19.23 \pm 1.6$ & $15.32 \pm 1.4$ \\
\hline 6 & $\mathbf{1 0 a}$ & $23.10 \pm 1.62$ & $27.50 \pm 1.09$ & $22.35 \pm 1.07$ \\
\hline 7 & $\mathbf{1 0 b}$ & $3.89 \pm 0.25$ & $4.01 \pm 0.35$ & $2.91 \pm 0.05$ \\
\hline 8 & $\mathbf{1 1 a}$ & $16.93 \pm 1.49$ & $28.07 \pm 1.3$ & $20.50 \pm 1.32$ \\
\hline 9 & $\mathbf{1 1 b}$ & $25.67 \pm 1.8$ & $35.08 \pm 1.23$ & $22.49 \pm 1.5$ \\
\hline 10 & $\mathbf{1 2}$ & $21.56 \pm 1.56$ & $28.12 \pm 1.28$ & $24.66 \pm 1.51$ \\
\hline 11 & Thalidomide & $11.26 \pm 0.54$ & $14.58 \pm 0.57$ & $16.87 \pm 0.7$ \\
\hline
\end{tabular}

\subsection{Molecular modeling}

\section{Docking studies}

To get insights on the binding mode of our compounds and their binding energy to Cereblon (CRBN), we carried out docking studies using molecular operating environment software (MOE). CRBN is the main target of thalidomide and its analogs(Mori et al. 2018) (Lopez-Girona et al. 2012). It is composed of three domains; 1- the amino terminal domain (NTD), 2- the $\alpha$-helical bundle domain (HBD), and 3- the carboxy-terminal domain (CTD) (Fuchs et al. 2014). CRBN is a part of damage-specific DNA binding protein 1 (DDB1)/cullin4 E3 ubiquitin ligase complex and plays pivotal role in the ubiquitination of substrate proteins, thus promoting their degradation. The ubiquitin ligase activity of this complex is altered by thalidomide CRBN binding (Matyskiela et al. 2016). The crystal structure of CRBN is now available at protein data bank (PDB) with ID 4TZC. Redocking of thalidomide into the protein showed root mean square deviation (RMSD) $1.34 \AA$ and docking score of $-14.22 \mathrm{kcal} / \mathrm{mol}$ (see Fig. 4). The binding mode of thalidomide to CRBN is shown in Fig.5. We can see that glutarimide moiety of thalidomide was able to accommodate the pocket and form two hydrogen bonds with His380 and Trp382 (see Fig. 6). Further cation $\pi$ interaction was observed between the nitrogen of phthalimide moiety and phenyl ring of Trp388. 


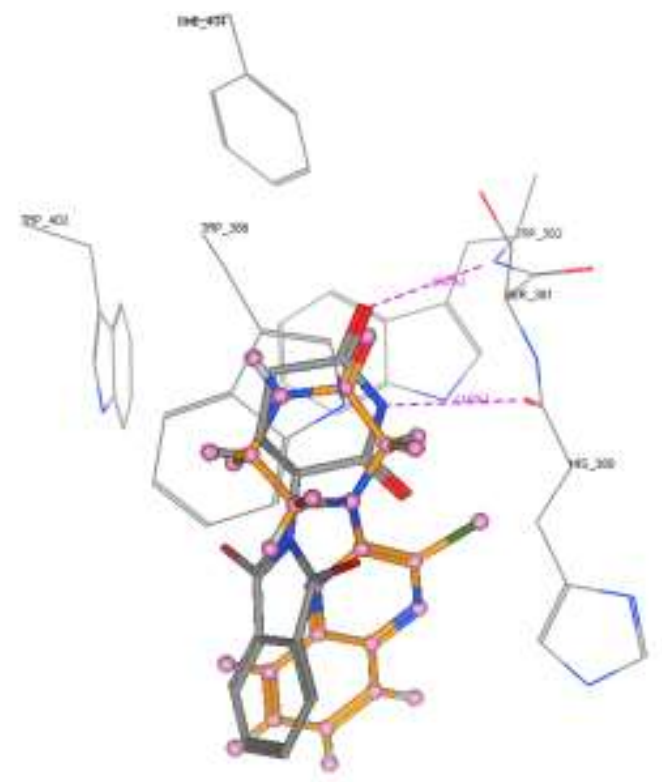

Figure 4: The overlay of the re-docked thalidomide molecule (grey colored molecule) and chloropiprazine derivative (the ligand) crystallized with CRBN (orange colored molecule).

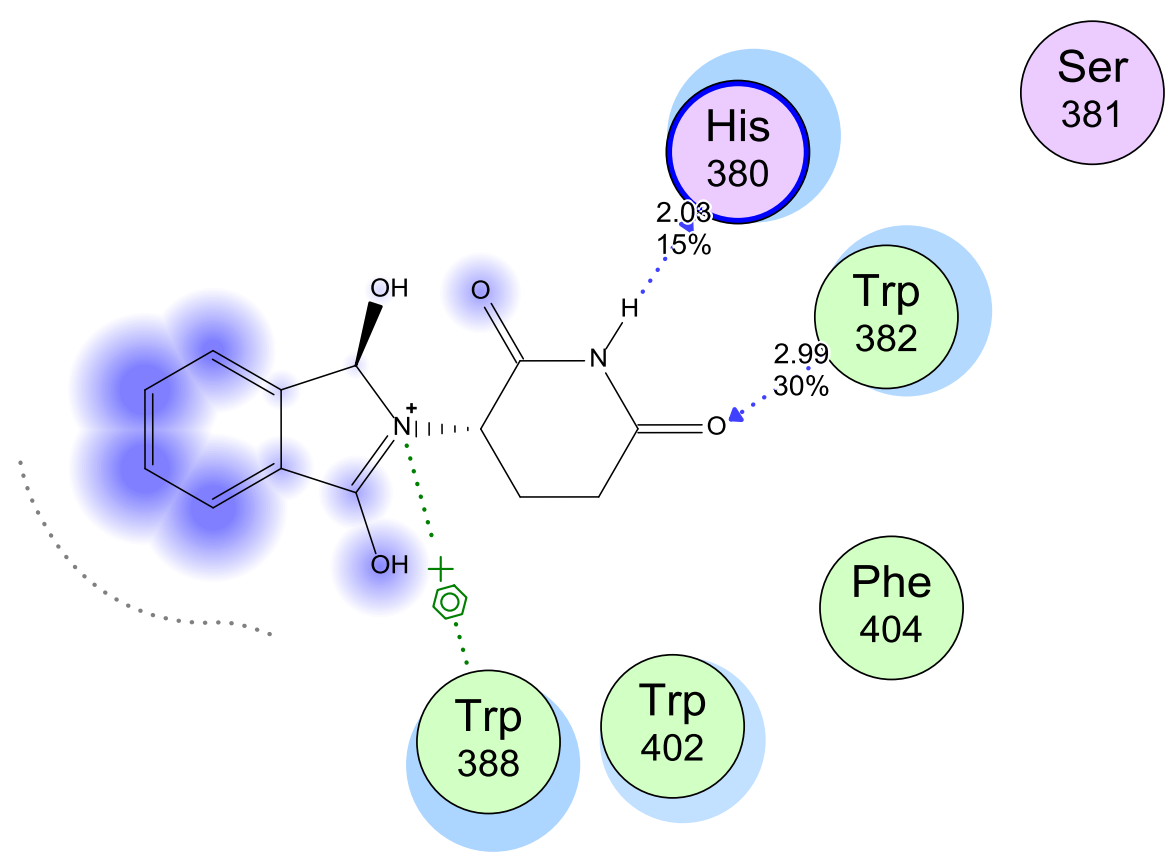

Figure 5: 2D diagram represents the accommodation and interaction of glutarimide moiety of thalidomide molecule inside the tri-Trp pocket of CRBN protein. 


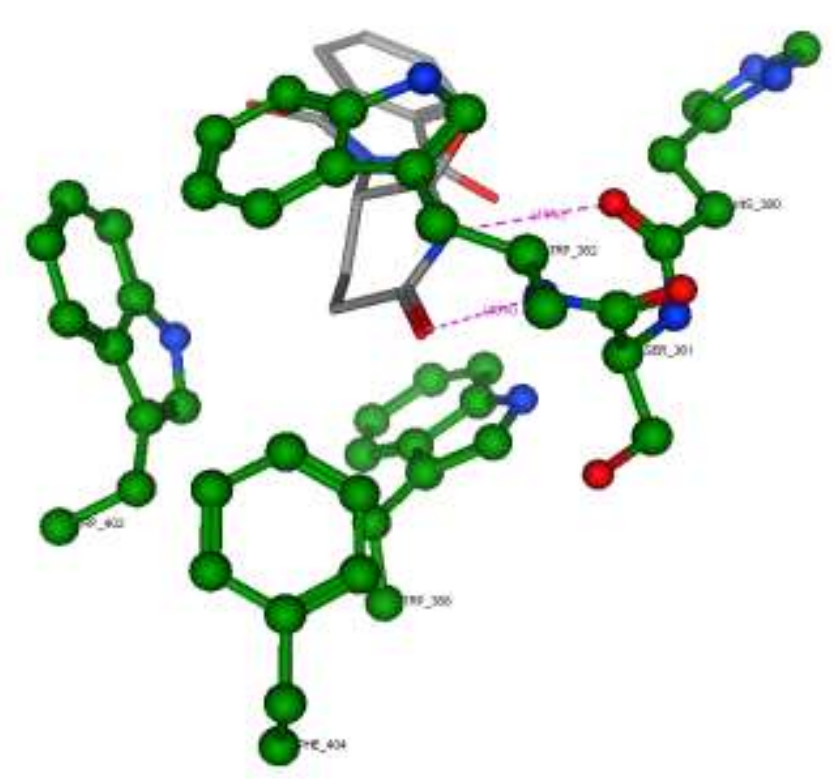

Figure 6: 3D diagram represents the accommodation and interaction of glutarimide moiety of thalidomide molecule inside the tri-Trp pocket of CRBN protein.

Our compounds docking results showed that all compounds exhibited binding energies too close to that of thalidomide (Table 2).

Table 2: Binding energies of our compounds and thalidomide to CRBN protein

\begin{tabular}{|l|l|l|}
\hline serial & Compound No. & Binding energy (Kcal./mol.) \\
\hline 1 & $\mathbf{6 a}$ & -13.2 \\
\hline 2 & $\mathbf{6 b}$ & -10.6 \\
\hline 3 & $\mathbf{7 a}$ & -12.7 \\
\hline 4 & $\mathbf{7 b}$ & -13.2 \\
\hline 5 & $\mathbf{8}$ & -13.1 \\
\hline 6 & $\mathbf{1 0 a}$ & -13.1 \\
\hline 7 & $\mathbf{1 0 b}$ & -10.3 \\
\hline 8 & $\mathbf{1 1 a}$ & -12.4 \\
\hline 9 & $\mathbf{1 1 b}$ & -14.1 \\
\hline 10 & $\mathbf{1 2}$ & -12.3 \\
\hline 11 & Thalidomide & -14.6 \\
\hline
\end{tabular}

With respect to binding modes of our compounds to CRBN, it was found that our compounds were able to accommodate the pocket to form interactions with the essential amino acids but in a manner differs than that of thalidomide. Fig. 7 shows that compound 10a formed one H.B. as well as $\pi \pi$ interaction with the essential residue His380. The H.B. was via the NH of quinoxalinone nucleus. We can see also further H.B. between the amidic carbonyl of 10a and Trp402. Cation $\pi$ interaction between the terminal phenyl ring and His399 can also be noticed (see Fig. 8). 


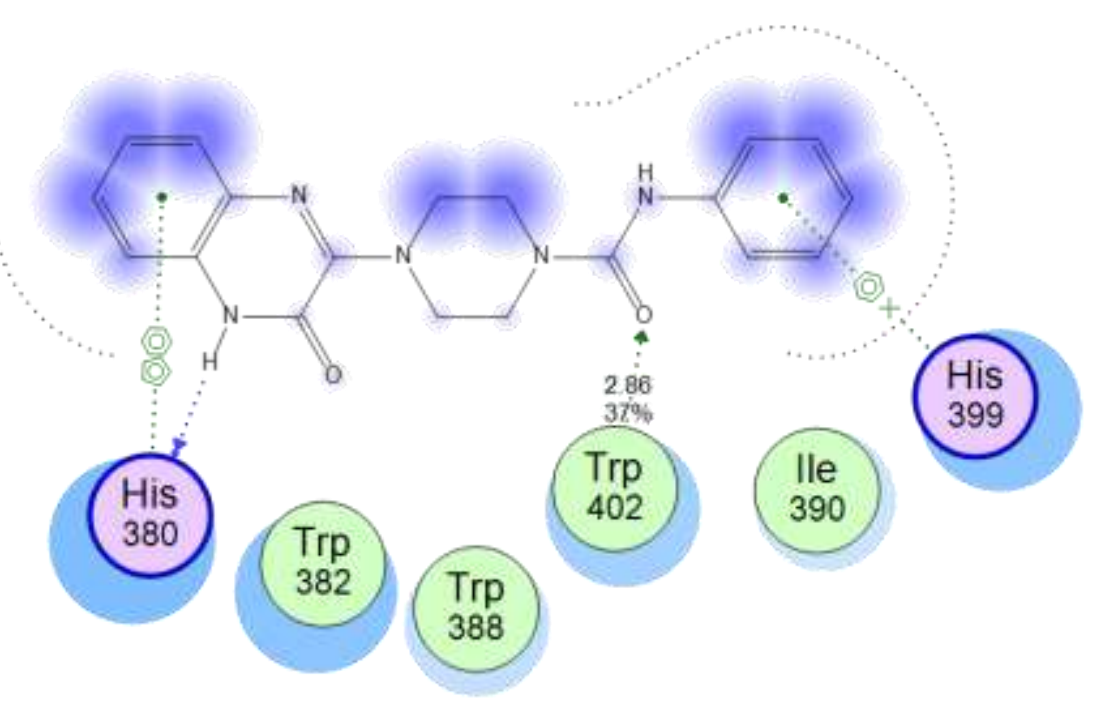

Figure 7: 2D diagram for binding mode of compound 10a

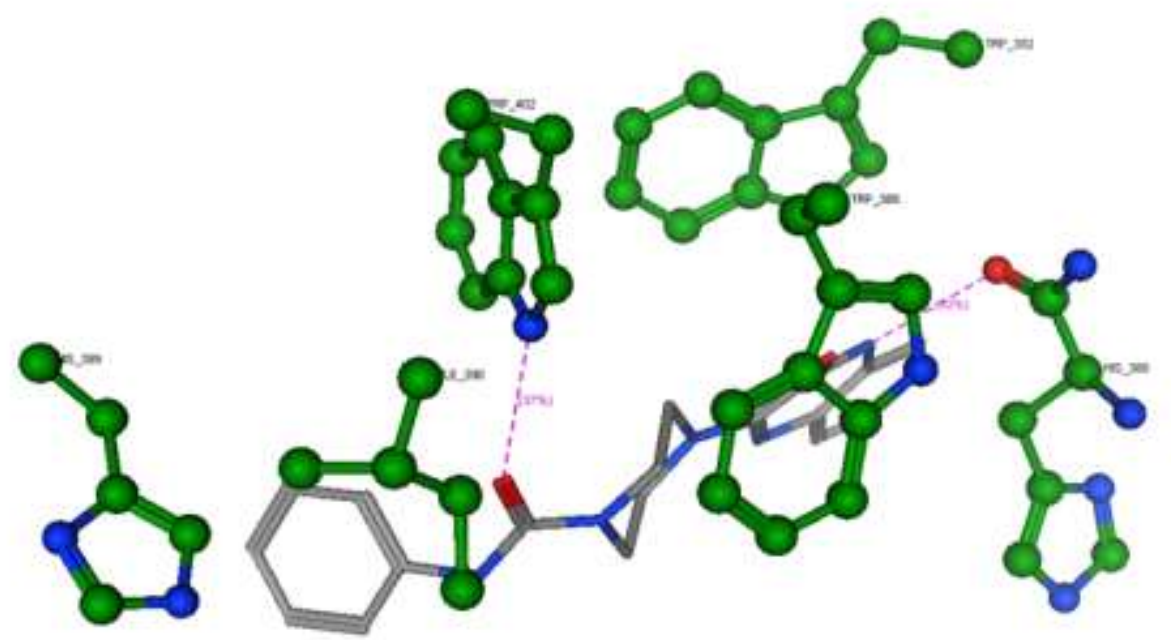

Figure 8: 3D diagram for binding mode of compound 10a

Compound $\mathbf{8}$ was found to form one $\pi \pi$ interaction and one cation $\pi$ interaction with the essential amino acid His380 as illustrated in Fig. 9. It can be seen that one H.B. is formed between its carbonyl and Trp402 (see Fig. 10). 


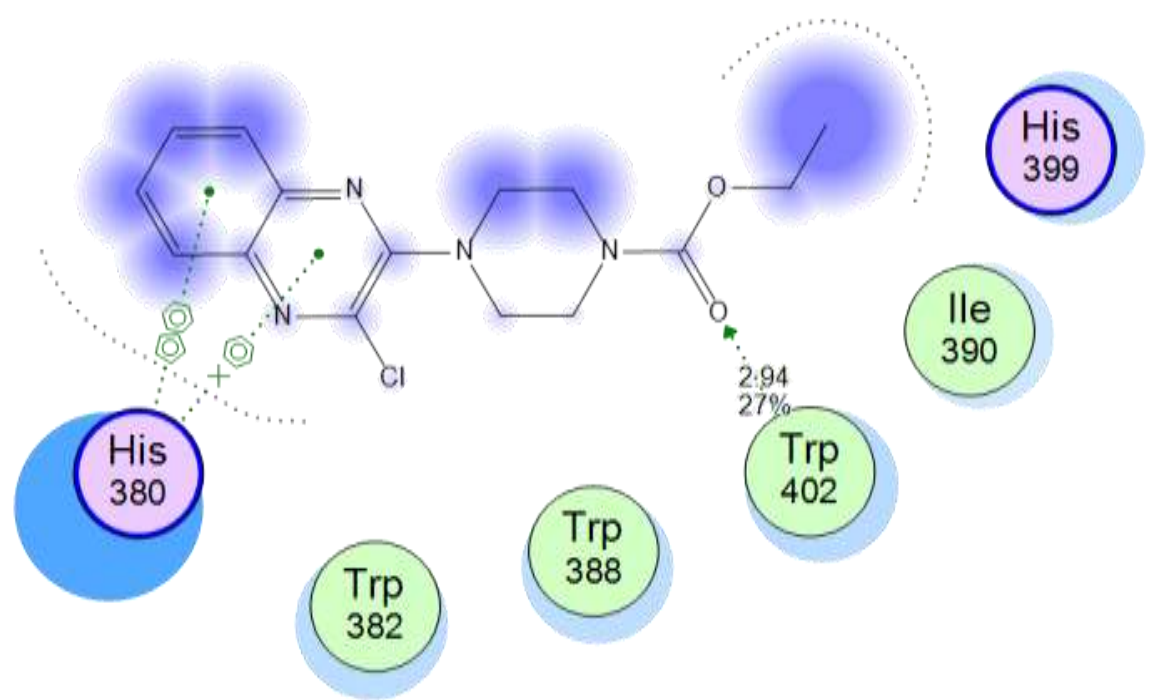

Figure 9: 2D diagram for binding mode of compound 8

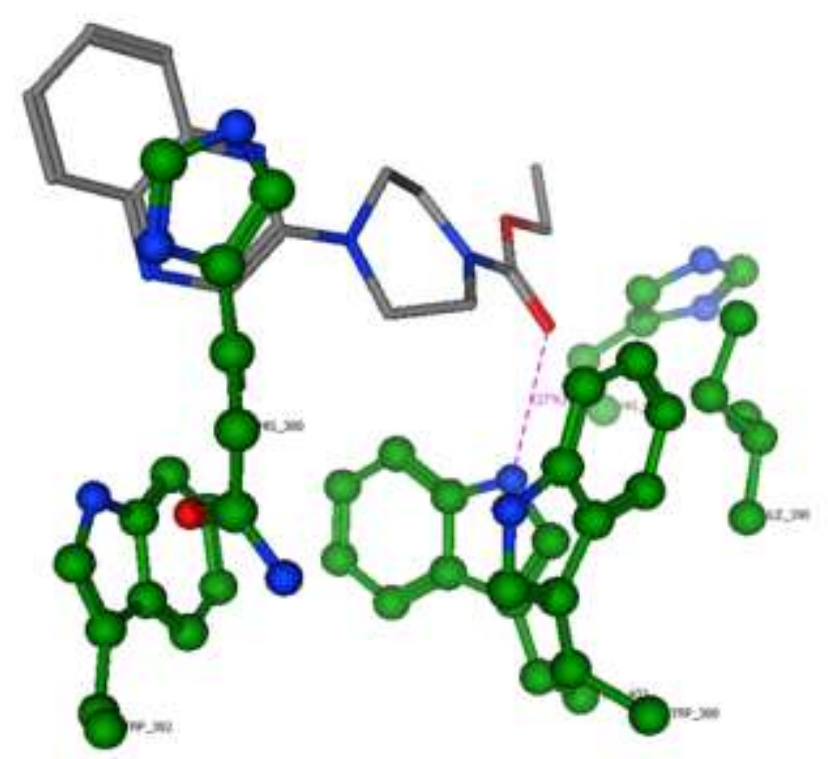

Figure 10: 3D diagram for binding mode of compound 8 


\subsection{Conclusion}

In our effort to develop new effective anticancer agents, we designed, synthesized and biologically evaluated ten new thalidomide analogs. Biological data showed that compound $\mathbf{1 0 b}$ is a promising thalidomide analog. So that this work suggests that compound $\mathbf{1 0 b}$ should be considered for further evaluation. It can also serve as a lead compound for future development of new effective anticancer agents.

\section{4- Materials and methods}

\subsection{Chemistry}

All melting points were carried out by open capillary method on a Gallen lamp Melting point apparatus and were uncorrected. Infrared spectra were recorded on Pye Unicam SP 1000 IR spectrophotometer ( $\mathrm{KBr}$ discs) and were expressed in wave number $\left(\mathrm{cm}^{-1}\right) .{ }^{1} \mathrm{H}$ NMR and ${ }^{13} \mathrm{C}$ NMR spectra were recorded on a BRUKER 100 MHZ-NMR Spectro-photometer. TMS was used as internal standard in deuterated DMSO and chemical shifts were measured in $\delta$ ppm. Progresses of the reaction was monitored by TLC using TLC sheets precoated with UV fluorescent silica gel Merck 60 F254 plates and were visualized using UV lamp.

4.1.1 General method for synthesis of compounds $6_{a \& b}$ : A mixture of the 2-Chloro-3piperazin-1-yl-quinoxaline $(1 \mathrm{mmol})$ and an appropriate isocyanate and/or isothiocyanate, namely, phenyl isocyanate and cyclohexyl isothiocyanate $(1.2 \mathrm{mmol})$ was refluxed in absolute ethanol $(50 \mathrm{ml})$ for $3 \mathrm{~h}$. The reaction mixture was cooled. The formed solid was filtered and recrystallized from ethanol to afford the corresponding compound $\mathbf{6}_{\mathbf{a} \& b}$, respectively.

4.1.1.1 4-(3-Chloroquinoxalin-2-yl)- $N$-phenylpiperazine-1-carboxamide $\left(6_{a}\right)$ (yield $87.62 \%$ ); m.p. $218-220{ }^{\circ} \mathrm{C}$; IR ( $\left.\mathrm{KBr}, \mathrm{cm}^{-1}\right)$ : $3302(\mathrm{NH}), 3059$ (C-H aromatic), 2908, 2881, 2846 (C-H aliphatic), 1635 (CO amide); ${ }^{1} \mathrm{H}$ NMR (DMSO-d 6 , $\left.400 \mathrm{MHz}\right) \delta$ (ppm): $8.64(\mathrm{~s}, 1 \mathrm{H}, \mathrm{CONH})\left(\mathrm{D}_{2} \mathrm{O}\right.$ exchangeable $), 7.90(\mathrm{~d}, J=8.2 \mathrm{~Hz}, 1 \mathrm{H}$, Ar-H quinoxaline), $7.85(\mathrm{~d}, J=8.3 \mathrm{~Hz}, 1 \mathrm{H}$, Ar-H quinoxaline), $7.75(\mathrm{dd}, J=7.7,7.7 \mathrm{~Hz}, 1 \mathrm{H}, \mathrm{Ar}-\mathrm{H}$ quinoxaline), $7.64(\mathrm{dd}, J=7.7,7.7 \mathrm{~Hz}, 1 \mathrm{H}, \mathrm{Ar}-\mathrm{H}$ quinoxaline), $7.49(\mathrm{~d}, J=8.0 \mathrm{~Hz}, 2 \mathrm{H}$, Ar-H), 7.25 (dd, $J=7.7,7.7 \mathrm{~Hz}, 2 \mathrm{H}, \mathrm{Ar}-\mathrm{H}), 6.95$ (t, $J=7.3 \mathrm{~Hz}, 1 \mathrm{H}, \mathrm{Ar}-\mathrm{H}), 3.68$ (t, $J=$ $4.5 \mathrm{~Hz}, 4 \mathrm{H} 2 \mathrm{CH}_{2}$ piperazine), $3.54\left(\mathrm{t}, J=4.5 \mathrm{~Hz}, 4 \mathrm{H}, 2 \mathrm{CH}_{2}\right.$ piperazine); Anal. Calcd. for $\mathrm{C}_{19} \mathrm{H}_{18} \mathrm{ClN}_{5} \mathrm{O}$ (367.84): C, 62.04; H, 4.93; N, 19.04. Found: C, 61.89; H, 5.12; N, $19.23 \%$.

4.1.1.2 4-(3-Chloroquinoxalin-2-yl)- $\boldsymbol{N}$-cyclohexylpiperazine-1-carbothioamide $\left(6_{\mathbf{b}}\right)$ (yield 84.09 \%); m.p. 145-147 ${ }^{\circ} \mathrm{C}$; IR (KBr, cm ${ }^{-1}$ ): $3286(\mathrm{NH}), 3039$ (C-H aromatic), 2981-2823 (C-H aliphatic); ${ }^{1} \mathrm{H}$ NMR (DMSO-d $\left.6,400 \mathrm{MHz}\right) \delta$ (ppm): 7.90 (dd, $J=8.2$, $1.4 \mathrm{~Hz}, 1 \mathrm{H}, \mathrm{Ar}-\mathrm{H}$ ), 7.84 (dd, $J=8.3,1.4 \mathrm{~Hz}, 1 \mathrm{H}, \mathrm{Ar}-\mathrm{H}), 7.76$ (ddd, $J=8.4,6.9,1.5 \mathrm{~Hz}$, $1 \mathrm{H}, \mathrm{Ar}-\mathrm{H}), 7.64$ (ddd, $J=8.3,6.9,1.4 \mathrm{~Hz}, 1 \mathrm{H}, \mathrm{Ar}-\mathrm{H}), 7.39(\mathrm{~d}, J=7.8 \mathrm{~Hz}, 1 \mathrm{H}, \mathrm{CSNH})$ $\left(\mathrm{D}_{2} \mathrm{O}\right.$ exchangeable $), 4.23(\mathrm{~m},, 1 \mathrm{H}, \mathrm{CH}$ of cyclohexyl $), 4.07-3.90\left(\mathrm{~m}, 4 \mathrm{H}, 2 \mathrm{CH}_{2}\right.$ piperazine $), 3.70-3.49\left(\mathrm{~m}, 4 \mathrm{H}, 2 \mathrm{CH}_{2}\right.$ piperazine $), 1.90-0.96\left(\mathrm{~m}, 10 \mathrm{H}, 5 \mathrm{CH}_{2}\right.$ of cyclohexyl); ${ }^{13} \mathrm{C}$ NMR (DMSO-d $\left.6,100 \mathrm{MHz}\right) \delta$ (ppm): 181.19, 152.36, 141.32, 139.84, 138.01, 131.07, 128.02, 127.83, 127.16, 55, 48.56, 47.12, 32.53, 25.75, 25.58 Anal. 
Calcd. for $\mathrm{C}_{19} \mathrm{H}_{24} \mathrm{ClN}_{5} \mathrm{~S}$ (389.95): C, 58.52; H, 6.20; N, 17.96. Found: C, 58.73; H, 6.30; $\mathrm{N}, 18.12 \%$.

\subsubsection{General method for synthesis of compounds $7_{\mathrm{a} \& \mathrm{~b}}$ :}

To a solution of 2-chloro-3-piperazin-1-yl-quinoxaline $(0.5 \mathrm{~g}, 2.01 \mathrm{mmol})$ and $\mathrm{Et}_{3} \mathrm{~N}(0.37 \mathrm{~g}, 0.50 \mathrm{ml}, 3.62 \mathrm{mmol})$ in DMF $(15 \mathrm{~mL})$, the appropriate 4-(un)substitutedbenzenesulfonyl chloride $(2.01 \mathrm{mmol})$, namely benzenesulfonyl chloride and 4-methyl was added in a drop wise manner while stirring in ice-salt bath for $1 \mathrm{~h}$. then the reaction mixture was slowly poured into ice-water with stirring. The obtained solid was filtered, washed with water and crystallized from ethanol to give the corresponding final compounds $\mathbf{7}_{\mathbf{a} \& b}$ respectively.

4.1.2.1 2-Chloro-3-(4-(phenylsulfonyl)piperazin-1-yl)quinoxaline (7 $\mathbf{7}_{\mathrm{a}}$ ) (yield 85.38 $\%$ ); m.p. 178-180 ${ }^{\circ} \mathrm{C}$; IR ( $\mathrm{KBr}, \mathrm{cm}^{-1}$ ): 3039 (C-H aromatic), 2920-2854 (C-H aliphatic), 1425, 1346 ( $\mathrm{SO}_{2}$ sulfonamide); ${ }^{1} \mathrm{H}$ NMR (DMSO-d 6 , $\left.400 \mathrm{MHz}\right) \delta(\mathrm{ppm}): 7.88(\mathrm{~d}, \mathrm{~J}=$ $8.2 \mathrm{~Hz}, 1 \mathrm{H}, \mathrm{Ar}-\mathrm{H}), 7.81$ (d, J = 7.7 Hz, 3H, Ar-H,), 7.75 (d, J = 7.0 Hz, 2H, Ar-H), 7.70 $(\mathrm{dd}, \mathrm{J}=7.4,5.9 \mathrm{~Hz}, 2 \mathrm{H}, \mathrm{Ar}-\mathrm{H}), 7.64(\mathrm{t}, \mathrm{J}=7.6 \mathrm{~Hz}, 1 \mathrm{H}, \mathrm{Ar}-\mathrm{H}), 3.57(\mathrm{t}, \mathrm{J}=4.8 \mathrm{~Hz}, 4 \mathrm{H}$, $2 \mathrm{CH}_{2}$ piperazine), $3.22-2.99\left(\mathrm{~m}, 4 \mathrm{H}, 2 \mathrm{CH}_{2}\right.$ piperazine); ${ }^{13} \mathrm{C} \mathrm{NMR}$ (DMSO-d 6,400 MHz) $\delta$ (ppm): 152.23, 141.56, 139.69, 138.16, 135.25, 133.94, 131.12, 130.03, 128.37, 128.07, 127.85, 127.21, 48.41, 45.99; Anal. Calcd. for $\mathrm{C}_{18} \mathrm{H}_{17} \mathrm{ClN}_{4} \mathrm{O}_{2} \mathrm{~S}$ (388.87): C, 55.60; H, 4.41; N, 14.41. Found: C, 55.82; H, 4.62; N, $14.65 \%$.

4.1.2.2 2-Chloro-3-(4-tosylpiperazin-1-yl)quinoxaline $\mathbf{( 7}_{\mathbf{b}}$ ) (yield $92.01 \%$ ); m.p. 185-187 ${ }^{\circ} \mathrm{C}$; IR (KBr, cm ${ }^{-1}$ ): 3062 (C-H aromatic), 2995-2850 (C-H aliphatic), 1427, $1342\left(\mathrm{SO}_{2}\right.$ sulfonamide); ${ }^{1} \mathrm{H}$ NMR (DMSO-d $\left.6,400 \mathrm{MHz}\right) \delta(\mathrm{ppm}): 7.86(\mathrm{~d}, J=8.2 \mathrm{~Hz}$, $1 \mathrm{H}, \mathrm{Ar}-\mathrm{H}), 7.80(\mathrm{~d}, J=8.3 \mathrm{~Hz}, 1 \mathrm{H}, \mathrm{Ar}-\mathrm{H}), 7.73(\mathrm{t}, J=7.7 \mathrm{~Hz}, 1 \mathrm{H}, \mathrm{Ar}-\mathrm{H}), 7.68(\mathrm{~d}, J=$ $7.8 \mathrm{~Hz}, 2 \mathrm{H}, \mathrm{Ar}-\mathrm{H}), 7.62(\mathrm{t}, J=7.6 \mathrm{~Hz}, 1 \mathrm{H}, \mathrm{Ar}-\mathrm{H}), 7.48(\mathrm{~d}, J=7.9 \mathrm{~Hz}, 2 \mathrm{H}, \mathrm{Ar}-\mathrm{H}, \mathrm{Ar}-\mathrm{H})$, $3.56(\mathrm{t}, J=4.8 \mathrm{~Hz}, 4 \mathrm{H}, 2 \mathrm{CH} 2$ piperazine), $3.10(\mathrm{t}, J=4.8 \mathrm{~Hz}, 4 \mathrm{H}, 2 \mathrm{CH} 2$ piperazine), 2.40 (s, 3H, $\mathrm{CH}_{3}$ ); Anal. Calcd. for $\mathrm{C}_{19} \mathrm{H}_{19} \mathrm{ClN}_{4} \mathrm{O}_{2} \mathrm{~S}$ (402.90): C, 56.64; H, 4.75; N, 13.91. Found: C, 56.78; H, 4.81; N, 14.15\%.

\subsubsection{General method for synthesis of compound 8}

To a solution of 2-chloro-3-piperazin-1-yl-quinoxaline $(0.5 \mathrm{~g}, 2.01 \mathrm{mmol})$ and $\mathrm{Et}_{3} \mathrm{~N}(0.41 \mathrm{~g}, 0.56 \mathrm{ml}, 4.02 \mathrm{mmol})$ in DCM $(15 \mathrm{~mL})$, ethyl chloroformate $(0.24 \mathrm{~g}, 0.21$ $\mathrm{ml}, 2.21 \mathrm{mmol}$ ) was added drop wise over a period of $0.5 \mathrm{~h}$. while stirring in ice salt bath. The reaction mixture was stirred for further $0.5 \mathrm{~h}$. The solvent was removed under vacuum and the obtained residue was washed with water, dried and crystallized from methanol.

4.1.3.1 Ethyl-4-(3-chloroquinoxalin-2-yl)piperazine-1-carboxylate (8) (Yield 90.01 \%); m.p. 132-134 ${ }^{\circ} \mathrm{C}$; IR (KBr, cm ${ }^{-1}$ ): 3016 (C-H aromatic), 2985-2847 (C-H aliphatic), $1693\left(\mathrm{C}=\mathrm{O}\right.$ amide); ${ }^{1} \mathrm{H}$ NMR (DMSO-d $\left.6,400 \mathrm{MHz}\right) \delta(\mathrm{ppm}): 7.77(\mathrm{~d}, J=8.2 \mathrm{~Hz}, 1 \mathrm{H}$, Ar-H), $7.71(\mathrm{~d}, J=8.3 \mathrm{~Hz}, 1 \mathrm{H}, \operatorname{Ar}-\mathrm{H}), 7.64(\mathrm{~d}, J=8.0 \mathrm{~Hz}, 1 \mathrm{H}, \operatorname{Ar}-\mathrm{H}), 7.55(\mathrm{t}, J=7.6$ $\mathrm{Hz}, 1 \mathrm{H}, \mathrm{Ar}-\mathrm{H}), 4.04\left(\mathrm{q}, J=7.1 \mathrm{~Hz}, 2 \mathrm{H}, \mathrm{OCH}_{2}-\mathrm{CH}_{3}\right), 3.52\left(\mathrm{~m}, 4 \mathrm{H}, 2 \mathrm{CH}_{2}\right.$ piperazine $)$, $3.44-3.33\left(\mathrm{~m}, 4 \mathrm{H}, 2 \mathrm{CH}_{2}\right.$ piperazine $), 1.17\left(\mathrm{t}, J=7.1 \mathrm{~Hz}, 3 \mathrm{H}, \mathrm{CH}_{3}\right)$; Anal. Calcd. for 
$\mathrm{C}_{15} \mathrm{H}_{17} \mathrm{ClN}_{4} \mathrm{O}_{2}$ (320.78): C, 56.17; H, 5.34; N, 17.47. Found: C, 56.39; H, 5.51; N, 17. $64 \%$.

4.1.4 General method for synthesis of compounds $10_{\mathrm{a} \& \mathrm{~b}}$ : A mixture of 3-(piperazin1-yl)quinoxalin-2(1H)-one (9) (1 $\mathrm{mmol})$ and an appropriate isocyanate and/or isothiocyanate, namely, phenyl isocyanate and cyclohexyl isothiocyanate $(1.2 \mathrm{mmol})$ was refluxed in absolute ethanol $(50 \mathrm{ml})$ for $3 \mathrm{~h}$. The reaction mixture was cooled. The formed solid was filtered and recrystallized from ethanol to afford the corresponding

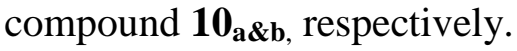

4.1.4.1 4-(3-Oxo-3,4-dihydroquinoxalin-2-yl)- $N$-phenylpiperazine-1-carbox-amide (10a) (yield 84.42 \%); m.p. 237-239 ${ }^{\circ} \mathrm{C}$; IR $\left(\mathrm{KBr}, \mathrm{cm}^{-1}\right)$ : $3390(2 \mathrm{NH}), 3062(\mathrm{C}-\mathrm{H}$ aromatic), 2978-2715 (C-H aliphatic), 1670, 1647 (C=O amide); ${ }^{1} \mathrm{H}$ NMR (DMSO-d 6 , $400 \mathrm{MHz}) \delta(\mathrm{ppm}): 12.16\left(\mathrm{~s}, 1 \mathrm{H}, \mathrm{NH}\right.$ quinoxaline, $\mathrm{D}_{2} \mathrm{O}$ exchangeable $), 8.58(\mathrm{~s}, 1 \mathrm{H}$, CONH, $\mathrm{D}_{2} \mathrm{O}$ exchangeable), $7.53-7.45(\mathrm{~m}, 2 \mathrm{H}, \mathrm{Ar}-\mathrm{H}), 7.43$ (ddd, $J=7.5,1.2 \mathrm{~Hz}, 1 \mathrm{H}$, Ar-H), $7.30-7.22(\mathrm{~m}, 2 \mathrm{H}$, Ar-H), 7.20 (dd, $J=3.7,1.1 \mathrm{~Hz}, 2 \mathrm{H}$, Ar-H), 7.16 (ddd, $J=$ 7.4, 5.1, 3.8 Hz, 1H, Ar-H), $6.99-6.91(\mathrm{~m}, 1 \mathrm{H}, \mathrm{Ar}-\mathrm{H}), 4.02-3.84\left(\mathrm{~m}, 4 \mathrm{H}, 2 \mathrm{CH}_{2}\right.$ piperazine), $3.67-3.52\left(\mathrm{~m}, 4 \mathrm{H}, 2 \mathrm{CH}_{2}\right.$ piperazine); Anal. Calcd. for $\mathrm{C}_{19} \mathrm{H}_{19} \mathrm{~N}_{5} \mathrm{O}_{2}$ (349.39): C, 65.32; H, 5.48; N, 20.04. Found: C, 65.18; H, 5.69; N, 19.87\%.

4.1.4.2 N-Cyclohexyl-4-(3-oxo-3,4-dihydroquinoxalin-2-yl)piperazine-1-carbothioamide $\left(\mathbf{1 0}_{\mathbf{b}}\right)$ (yield $81.49 \%$ ); m.p. $235-237^{\circ} \mathrm{C}$; $\mathrm{IR}\left(\mathrm{KBr}, \mathrm{cm}^{-1}\right): 3379,3344(2 \mathrm{NH})$, 3020 (C-H aromatic), 2981-2777 (C-H aliphatic), 1662 (C=O amide); ${ }^{1} \mathrm{H}$ NMR (DMSO- $\left.\mathrm{d}_{6}, 400 \mathrm{MHz}\right) \delta(\mathrm{ppm}): 12.13\left(\mathrm{~s}, 1 \mathrm{H}, \mathrm{NH}\right.$ quinoxaline, $\mathrm{D}_{2} \mathrm{O}$ exchangeable), 7.41 (d, $J=7.4 \mathrm{~Hz}, 1 \mathrm{H}, \mathrm{CSNH}, \mathrm{D}_{2} \mathrm{O}$ exchangeable), 7.29 (d, $J=7.7 \mathrm{~Hz}, 1 \mathrm{H}$, Ar-H), $7.23-$ $7.08(\mathrm{~m}, 3 \mathrm{H}, \mathrm{Ar}-\mathrm{H}), 4.21(\mathrm{~m}, 1 \mathrm{H}, \mathrm{CH}$ cyclohexyl), $3.93(\mathrm{~m}, J=5.6 \mathrm{~Hz}, 8 \mathrm{H}, 4 \mathrm{CH} 2$ piperazine), $1.90-1.04\left(\mathrm{~m}, 10 \mathrm{H}, 5 \mathrm{CH}_{2}\right.$ cyclohexyl); ${ }^{13} \mathrm{C}$ NMR (DMSO-d $\left.6,100 \mathrm{MHz}\right) \delta$ (ppm): 180.79, 152.5, 151.34, 132.69, 129.68, 125.58, 125.2, 123.68, 114.87, 54.95, 47.14, 45.98, 32.55, 25.73, 25.58; Anal. Calcd. for $\mathrm{C}_{19} \mathrm{H}_{25} \mathrm{~N}_{5} \mathrm{OS}$ (371.50): C, 61.43; H, $6.78 ; \mathrm{N}, 18.85$. Found: C, 61.60; H, 6.71; N, $19.02 \%$.

\subsubsection{General method for synthesis of compounds $11_{\mathrm{a} \& \mathrm{~b}}$ :}

To a solution of 3-(piperazin-1-yl)quinoxalin-2(1H)-one (9) $(2.01 \mathrm{mmol})$ and $\mathrm{Et}_{3} \mathrm{~N}(0.37 \mathrm{~g}, 0.50 \mathrm{ml}, 3.62 \mathrm{mmol})$ in DMF (15 mL), an appropriate 4-(un)substituted benzenesulfonyl chloride $(2.01 \mathrm{mmol})$, namely benzenesulfonyl chloride and 4methylbenzenesulfonyl chloride was added in a drop wise manner while stirring in icesalt bath for $1 \mathrm{~h}$. then the reaction mixture was slowly poured into ice-water with stirring. The obtained solid was filtered, washed with water and crystallized from ethanol to give the corresponding final compounds $\left(\mathbf{1 1}_{\mathbf{a} \& \mathbf{b}}\right)$ respectively.

4.1.5.1 3-(4-(Phenylsulfonyl)piperazin-1-yl)quinoxalin-2(1H)-one (11 $\mathbf{a})$ (Yield 82.37 $\%$ ); m.p. 238-240 ${ }^{\circ} \mathrm{C}$; IR (KBr, cm $\left.{ }^{-1}\right): 3448(\mathrm{NH}), 3055$ (C-H aromatic), 2985-2762 (C$\mathrm{H}$ aliphatic), 1662 (C=O amide), 1492, $1346\left(\mathrm{SO}_{2}\right.$ sulfonamide); ${ }^{1} \mathrm{H}$ NMR (DMSO-d ${ }_{6}$, $400 \mathrm{MHz}) \delta$ (ppm): $12.16\left(\mathrm{~s}, 1 \mathrm{H}, \mathrm{NH}, \mathrm{D}_{2} \mathrm{O}\right.$ exchangeable), $7.87-7.77$ (m, 2H, Ar-H), 7.48 (t, $J=8.8 \mathrm{~Hz}, 2 \mathrm{H}, \mathrm{Ar}-\mathrm{H}), 7.37$ (dd, $J=7.9,1.4 \mathrm{~Hz}, 1 \mathrm{H}, \mathrm{Ar}-\mathrm{H}), 7.23-7.08$ (m, 4H, Ar-H), $3.98\left(\mathrm{t}, J=4.8 \mathrm{~Hz}, 4 \mathrm{H}, 2 \mathrm{CH}_{2}\right.$ piperazine), $3.04(\mathrm{t}, J=5.0 \mathrm{~Hz}, 4 \mathrm{H}, 2 \mathrm{CH} 2$ piperazine); ${ }^{13} \mathrm{C}$ NMR (DMSO-d 6 , $\left.400 \mathrm{MHz}\right) \delta$ (ppm): 166.44, 163.93, 152.34, 151.19, 
132.33, 131.55, 131.52, 131.22,131.12, 129.81, 125.68, 125.57, 123.69, 117.26, 117.03, 114.88, 46.16, 45.69; Anal. Calcd. for $\mathrm{C}_{18} \mathrm{H}_{18} \mathrm{~N}_{4} \mathrm{O}_{3} \mathrm{~S}$ (370.43): C, 58.36; H, 4.90; N, 15.13. Found: C, 58.58; H, 5.11; N, $15.40 \%$.

4.1.5.2 3-(4-Tosylpiperazin-1-yl)quinoxalin-2(1H)-one (11 $\left.\mathbf{1}_{\mathbf{b}}\right) \quad$ (Yield 90.19\%); m.p. 245-247 ${ }^{\circ} \mathrm{C}$; IR $\left(\mathrm{KBr}, \mathrm{cm}^{-1}\right): 3417(\mathrm{NH}), 3020$ (C-H aromatic), 2981-2777 (C-H aliphatic), 1666 (C=O amide), 1489, $1332\left(\mathrm{SO}_{2}\right.$ sulfonamide); ${ }^{1} \mathrm{H}$ NMR (DMSO-d 6 , 400 $\mathrm{MHz}) \delta(\mathrm{ppm}): 12.15$ (s, 1H, NH, $\mathrm{D}_{2} \mathrm{O}$ exchangeable), 7.65 (d, $J=7.9 \mathrm{~Hz}, 2 \mathrm{H}$, Ar-H), $7.41(\mathrm{~m}, 3 \mathrm{H}, \mathrm{Ar}-\mathrm{H}), 7.22-7.06(\mathrm{~m}, 3 \mathrm{H}, \mathrm{Ar}-\mathrm{H}), 3.96\left(\mathrm{t}, J=4.9 \mathrm{~Hz}, 4 \mathrm{H}, 2 \mathrm{CH}_{2}\right.$ piperazine), $3.00\left(\mathrm{t}, J=4.9 \mathrm{~Hz}, 4 \mathrm{H}, 2 \mathrm{CH}_{2}\right.$ piperazine), $2.39\left(\mathrm{~s}, 3 \mathrm{H}, \mathrm{CH}_{3}\right) ;{ }^{13} \mathrm{C} \mathrm{NMR}$ $\left(\right.$ DMSO$\left._{6}, 400 \mathrm{MHz}\right) \delta(\mathrm{ppm}): 152.33,151.21,144.32,132.33,132.08,130.36$, 129.81, 128.12, 125.67, 125.58, 123.7, 114.89, 46.19, 45.7, 21.45; Anal. Calcd. for $\mathrm{C}_{19} \mathrm{H}_{20} \mathrm{~N}_{4} \mathrm{O}_{3} \mathrm{~S}$ (384.45): C, 59.36; H, 5.24; N, 14.57. Found: $\mathrm{C}, 59.54 ; \mathrm{H}, 5.33 ; \mathrm{N}$, $14.79 \%$.

\subsubsection{General method for synthesis of compound 12}

To a solution of 3-(piperazin-1-yl)quinoxalin-2(1H)-one $(2.01 \mathrm{mmol})$ and $\mathrm{Et}_{3} \mathrm{~N}(0.41 \mathrm{~g}$, $0.56 \mathrm{ml}, 4.02 \mathrm{mmol})$ in DCM $(15 \mathrm{~mL})$, ethyl chloroformate $(0.24 \mathrm{~g}, 0.21 \mathrm{ml}, 2.21$ mmol) was added drop wise over a period of $0.5 \mathrm{~h}$. while stirring in ice salt bath. The reaction mixture was stirred for further $0.5 \mathrm{~h}$. The solvent was removed under vacuum and the obtained residue was washed with water, dried and crystallized from methanol.

4.1.6.1 Ethyl 4-(3-oxo-3,4-dihydroquinoxalin-2-yl)piperazine-1-carboxylate (12) (yield $95.00 \%$ ); m.p. 203-205 ${ }^{\circ} \mathrm{C}$; IR $\left(\mathrm{KBr}, \mathrm{cm}^{-1}\right)$ : $3425(\mathrm{NH}), 3093(\mathrm{C}-\mathrm{H}$ aromatic), 2981-2777 (C-H aliphatic), 1708 ( $\mathrm{C}=\mathrm{O}$ ester), 1674 ( $\mathrm{C}=\mathrm{O}$ amide); ${ }^{1} \mathrm{H}$ NMR (DMSO- $\mathrm{d}_{6}$, $400 \mathrm{MHz}) \delta(\mathrm{ppm}): 12.17\left(\mathrm{~s}, 1 \mathrm{H}, \mathrm{NH}, \mathrm{D}_{2} \mathrm{O}\right.$ exchangeable), $7.41(\mathrm{dt}, \mathrm{J}=7.5,1.2 \mathrm{~Hz}, 1 \mathrm{H}$, Ar-H), $7.17(\mathrm{~m}, 3 \mathrm{H}, \mathrm{Ar}-\mathrm{H}), 4.08\left(\mathrm{q}, J=7.1 \mathrm{~Hz}, 2 \mathrm{H}, \mathrm{OCH}_{2}-\mathrm{CH}_{3}\right), 3.92-3.82(\mathrm{~m}, 4 \mathrm{H}$, $2 \mathrm{CH}_{2}$ piperazine), $3.50(\mathrm{t}, J=5.1 \mathrm{~Hz}, 4 \mathrm{H}, 2 \mathrm{CH} 2$ piperazine $), 1.21(\mathrm{t}, J=7.1 \mathrm{~Hz}, 3 \mathrm{H}$, $\mathrm{CH}_{3}$ ); Anal. Calcd. for $\mathrm{C}_{15} \mathrm{H}_{17} \mathrm{ClN}_{4} \mathrm{O}_{2}$ (320.78): C, 59.59; H, 6.00; N, 18.53. Found: $\mathrm{C}$, $59.80 ; \mathrm{H}, 6.18 ; \mathrm{N}, 18.87 \%$.

\subsection{Biological testing}

\section{Cell lines}

The cell lines were obtained from ATCC via Holding company for biological products and vaccines (VACSERA), Cairo, Egypt.

\section{Chemical reagents}

The reagents used are RPMI-1640 medium, MTT and DMSO (sigma co., St. Louis, USA) and Fetal Bovine serum (GIBCO).

\section{Antiproliferative assay}

The different cell lines mentioned above were used to determine the inhibitory effects of compounds on cell growth using the MTT assay. This colorimetric assay is 
based on the conversion of the yellow tetrazolium bromide (MTT) to a purple formazan derivative by mitochondrial succinate dehydrogenase in viable cells. The cells were cultured in RPMI-1640 medium with $10 \%$ fetal bovine serum. Antibiotics added were 100 units $/ \mathrm{ml}$ penicillin and $100 \mu \mathrm{g} / \mathrm{ml}$ streptomycin at $37 \mathrm{C}$ in a $5 \% \mathrm{CO}_{2}$ incubator. The cells were seeded in a 96-well plate at a density of $1.0 \times 10^{4}$ cells/well. at $37 \mathrm{C}$ for $48 \mathrm{~h}$ under $5 \% \mathrm{CO}_{2}$. After incubation the cells were treated with different concentration of compounds and incubated for $24 \mathrm{~h}$. After $24 \mathrm{~h}$ of drug treatment, $20 \mu \mathrm{l}$ of MTT solution at $5 \mathrm{mg} / \mathrm{ml}$ was added and incubated for $4 \mathrm{~h}$. Dimethyl sulfoxide (DMSO) in volume of $100 \mu \mathrm{l}$ is added into each well to dissolve the purple formazan formed. The colorimetric assay is measured and recorded at absorbance of $570 \mathrm{~nm}$ using a plate reader (EXL 800, USA). The relative cell viability in percentage was calculated as (A570 of treated samples/A570 of untreated sample) X 100.

\subsection{Molecular modeling}

To study the binding interaction and measure the binding energy of the newly synthesized compounds within CRBN protein, docking studies for these compounds were performed. Crystal structures of CRBN protein is available on protein data bank (PDB) website. Docking studies were done on CRBN (PDB ID: 4TZC) by MOE software. Protein was downloaded from PDB website to be opened on MOE. Water molecules deletion, energy minimization and addition of hydrogen atoms were done. The re-docking of the co-crystallized thalidomide molecule into CRBN protein validated the docking process.

\section{REFERENCES}

Akobeng, Anthony K., and Pieter C. Stokkers. 2009. "Thalidomide and Thalidomide Analogues for Maintenance of Remission in Crohn's Disease." Cochrane Database of Systematic Reviews.

Attal, Michel et al. 2012. "Lenalidomide Maintenance after Stem-Cell Transplantation for Multiple Myeloma." New England Journal of Medicine.

Diggle, G E. 2001. “Thalidomide: 40 Years On.” International journal of clinical practice.

Mac Donald, Paula. 2012. “Chemotherapeutic Drugs.” In Emergencies in Pediatric Oncology,.

Eleutherakis-Papaiakovou, V., A. Bamias, and M. A. Dimopoulos. 2004.

"Thalidomide in Cancer Medicine." Annals of Oncology.

Fernández-Lázaro, Diego, César Ignacio Fernández-Lázaro, Alberto Caballeroía Garc, and Alfredo Córdova Martínez. 2018. "Immunomodulator Drugs for the Treatment of Multiple Myeloma." Revista Medica de Chile.

Fuchs, Ota et al. 2014. International Journal of Hematological Disorders Cereblon and Its Role in the Treatment of Multiple Myeloma by Lenalidomide or 
Pomalidomide.

Galustian, C., and A. G. Dalgleish. 2011. "Pomalidomide. TNF- $\alpha$ Production Inhibitor, Treatment of Multiple Myeloma, Treatment of Myelofibrosis." Drugs of the Future.

Hagner, Patrick R. et al. 2015. "CC-122, a Pleiotropic Pathway Modifier, Mimics an Interferon Response and Has Antitumor Activity in DLBCL.” Blood.

Ito, Takumi et al. 2010. "Identification of a Primary Target of Thalidomide Teratogenicity." Science.

Ito, Takumi, Hideki Ando, and Hiroshi Handa. 2011. "Teratogenic Effects of Thalidomide: Molecular Mechanisms." Cellular and Molecular Life Sciences.

Jemal, A. et al. 2008. "Cancer Statistics, 2008." CA: A Cancer Journal for Clinicians.

Jin, Xin et al. 2013. "Thalidomide: Features and Potential Significance in Oral Precancerous Conditions and Oral Cancer." Journal of Oral Pathology and Medicine.

Lopez-Girona, A. et al. 2012. "Cereblon Is a Direct Protein Target for Immunomodulatory and Antiproliferative Activities of Lenalidomide and Pomalidomide." Leukemia.

Matyskiela, Mary E. et al. 2016. "A Novel Cereblon Modulator Recruits GSPT1 to the CRL4 CRBN Ubiquitin Ligase.” Nature.

Mori, Tomoyuki et al. 2018. "Structural Basis of Thalidomide Enantiomer Binding to Cereblon." Scientific Reports.

Offidani, Massimo et al. 2014. "Pomalidomide for the Treatment of RelapsedRefractory Multiple Myeloma: A Review of Biological and Clinical Data.” Expert Review of Anticancer Therapy.

Okafor, Mark C. 2003. "Thalidomide for Erythema Nodosum Leprosum and Other Applications." Pharmacotherapy.

P., Hagner et al. 2014. "CC-122 Has Potent Anti-Lymphoma Activity through Destruction of the Aiolos and Ikaros Transcription Factors and Induction of Interferon Response Pathways." Blood.

Siegel, Rebecca L., Kimberly D. Miller, and Ahmedin Jemal. 2020. "Cancer Statistics, 2020." CA: A Cancer Journal for Clinicians.

Singhal, Seema et al. 1999. "Antitumor Activity of Thalidomide in Refractory Multiple Myeloma." New England Journal of Medicine. 
T., Ito et al. 2010. "Identification of a Primary Target of Thalidomide Teratogenicity." Science.

\section{تصميم ونمذجه جزيئية وتثبا عوامل جديدة منظمة لجهاز المناعة لارستها بيولوجيا}

$$
\begin{aligned}
& \text { 'ماجد محمد صالح الورد ـ 'رزق رزق عياد ـ 'محمد فتح اله زايد- 'عبداله عمارة عبدالهـ '*محد أيمن الذهبي } \\
& \text { 'قسم الكيمياء الصيدلية و التصميم الدوائي ـ كلية الصيدلة ـ جامعه الازهر (بنين) القاهرة - مصر } \\
& \text { malzahaby@azhar.edu.eg: البريد الالكتروني للباحث الرئيسي }
\end{aligned}
$$

$$
\text { الملخص العربى }
$$

السرطان هو السبب الرئيسي الثناني للوفاة في جميع أنحاء العالم. هذا العمل هو محاولة لإيجاد عوامل

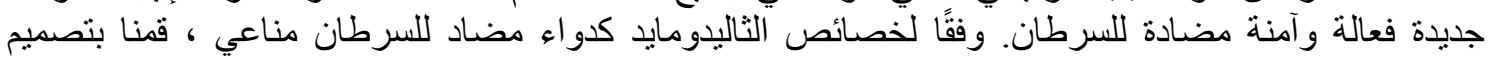

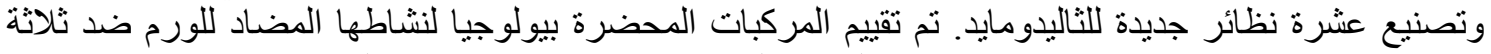

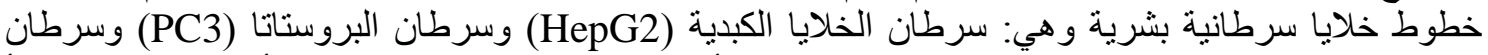

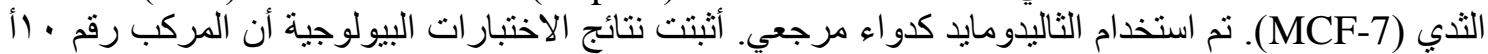

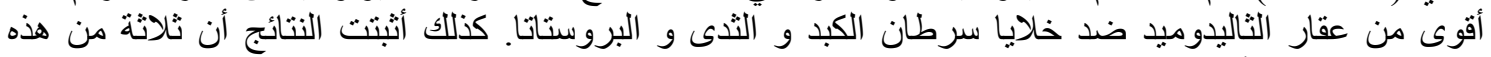

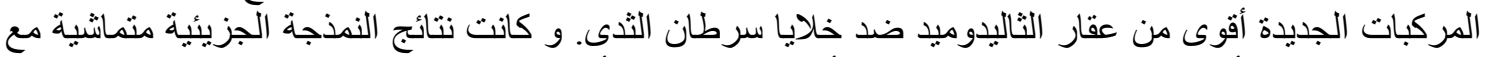

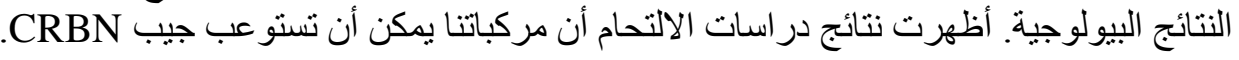

الكلمات المفتحية : مضاد للسرطان, منظم لجهاز المناعة و عقار الثاليدوميد 